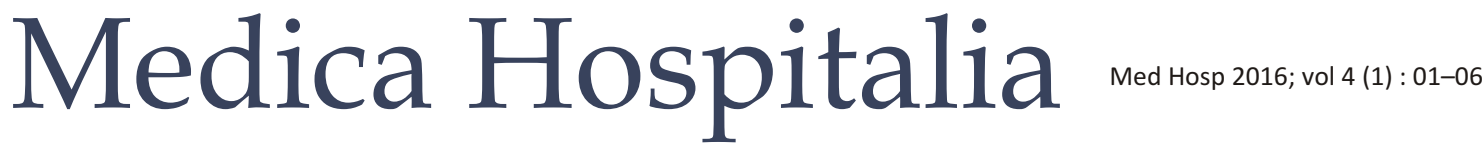

Review Article

Medical Progress

\section{"Disorder of Sex Development" : Problem yang dihadapi di Indonesia}

\author{
Asri Purwanti \\ Bagian/SMF IImu Kesehatan Anak Fakultas Kedokteran Universitas Diponegoro/RSUP Dr. Kariadi Semarang
}

\section{PENDAHULUAN}

Disorders of Sex Development (DSD) adalah suatu kelainan kongenital di manaperkembangan alat kelamin di tingkat kromosom, gonad, atau anatomi terjadi secara atipikal. DSD ditandai dengan adanya organ genitalia eksterna yang tidak jelas laki-laki atau perempuan, atau mempunyai gambaran kedua jenis kelamin. Dicurigai ambiguous genitalia apabila alat kelamin penis telalu kecil atau klitoris terlalu besar atau bilamana skrotum melipat garis tengah sehingga tampak seperti labia mayora yang tidak normal dan gonad tidak teraba. ${ }^{1}$

Penegakkan diagnosis secepat mungkin dan penatalaksaan sangat penting sehingga dapat segera dilakukan untuk meminimalisasi komplikasi medis, psikologis dan sosial. ${ }^{2}$ Upaya medis untuk menyesuaikan atau memperbaiki bentuk kelamin seringkali diikuti oleh beberapa masalah yang terkait dari segi medis, psikososial, hukum, lingkungan hingga agama. Tujuan penulisan ini adalah untuk memaparkan tentang DSD dan problem yang dihadapi di Indonesia.

\section{EPIDEMIOLOGI}

Insiden Disorders of sex development (DSD) adalah $1: 4500-1: 5000$ bayi lahir hidup. Dimana 50\% kasus 46, XY dapat diketahui penyebabnya dan 20\% secara keseluruhan dapat diagnosis secara molekular. Di Semarang jumlah penderita yang datang rata-rata 2 orang perminggu. Sejak tahun 1991 jumlah penderita yang terdaftar pada laboratorium Sitogenetika Pusat Riset Biomedik FK Undip Semarang untuk pemeriksaan kromosom (sebagai penentu jenis kelamin) $>400$ orang. $^{3}$ Namun sebagian kasus ambiguitas seksual itu memeriksakan diri saat anak itu sudah berusia di atas 2 tahun bahkan sudah beranjak dewasa dengan pengasuhan gender yang tidak sesuai, sehingga keadaan ini sangat memprihatinkan di Indonesia.

\section{ETIOLOGI}

Penyebab penyakit ambigus genitalia, terbanyak oleh karena kelainan genetik, namun pengaruh lingkungan terutama penggunaan obat-obat hormonal pada masa kehamilan merupakan salah satu penyebabnya. Pemakaian obat-obat hormonal yang tidak diperlukan dapat mengakibatkan paparan selama masa kehamilan sehingga mengakibatkan abnormalitas perkembangan genitalia pada akhirnya.

\section{PATOFISIOLOGI}

Pemahaman terhadap diferensiasi seksual yang normal dan abnormal adalah penting untuk memahami ambigus genitalia. Berikut adalah proses embriologi dan klasifikasi pada ambigous genitalia: ${ }^{4}$

\section{Embriologi Diferensiasi Seksual}

Penentuan fenotip seks di mulai dari seks genetik yang kemudian di ikuti oleh kaskade: kromosom seks menentukan seks gonad, akhirnya menentukan fenotip seks. Tipe gonad menentukan diferensiasi atau regresi duktus internal (milleri dan wolfii). Indentitas gender tidak hanya di tentukan oleh fenotip individu, tetapi juga oleh perkembangan otak natal dan prenatal.

\section{Diferensiasi gonad}

Dalam bulan ke dua kehidupan fetus, gonad indeferen di pandu menjadi tetes informasi genetik yang ada pada lengan pendek kromosom $\mathrm{Y}$ disebut tetes determining faktor (DTF) merupakan rangkaian 35-kbp dalam subband 11,3, area ini disebut daerah penentu seks pada kromosom Y (SRY), bila mana daerah ini tidak ada atau berubah, maka gonad dalam perkembangan tetes antara lain DAX I pada pada kromosom X. SFI pada gq33,WTI pada 11p 13,SOX 9 pada 17q24-q25, dan AMH pada 19q 13.5 


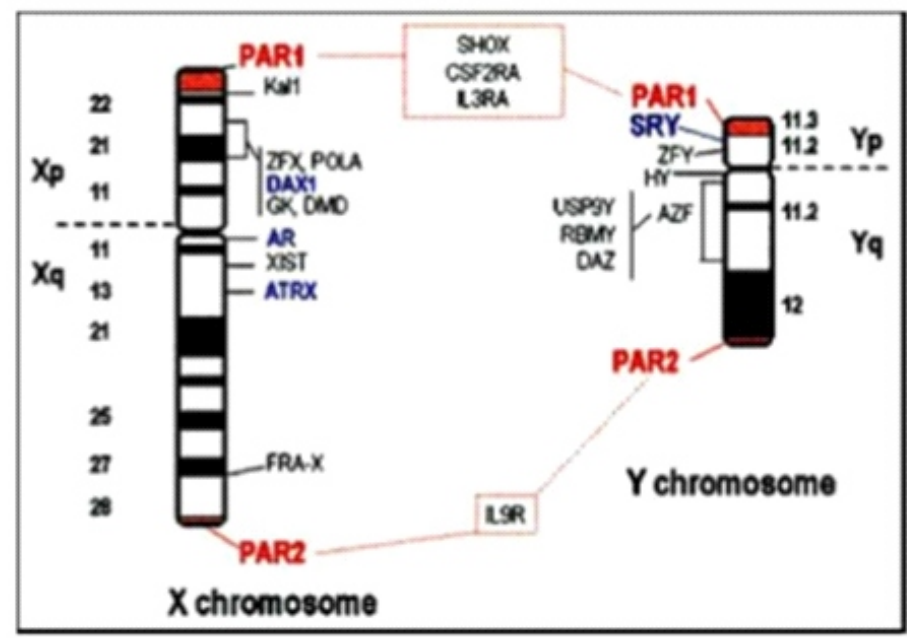

Gambar 1. Pemetaan Gen yang berhubungan dengan Penentuan Seks ${ }^{4}$

\section{Diferensiasi saluran internal}

Perkembangan duktus internal pada akibat efek parakrin gonad ipsilateral. Bila ada jaringan testis, maka ada 2 subtansi produk internal laki-laki yaitu testosteron substansi penghambat milleri (MIS) atau hormon anti milleri $(\mathrm{AMH})$.

Testosteron di produksi sel leydig testis, merangsang duktus wolfi menjadi epidimidis, vas deferens dan vesikula seminalis. Struktur wolfi paling dekat dengan sumber testosteron, duktus wolfi tidak berkembang seperti yang diharapkan bila testes atau gonad disgenetik sehingga tidak memproduksi testosteron. Kadar testosteron lokal yang tinggi penting untuk diferensiasi duktus wolfi namun pada fetus perempuan androgen ibu saja yang tinggi tidak dapat menyebabkan deferensiasi duktus internal laki-laki, hal ini juga tidak terjadi pada bayi perempuan dengan congenital adrenal hiperplasia (CAH) ${ }^{4}$

\section{Deferensiasi genetalia eksternal}

Genitalia kedua jenis kelamin masih identik sampai 7 minggu pertama masa gestasi. Tanpa hormon endrogen (testosteron dan dihidrotestesteron-DHT), genitalia eksterna secara fenotip perempuan. Bila ada gonad lakilaki, diferensiasi terjadi secara aktif setelah minggu ke-8 menjadi fenotip laki-laki. Diferensi ini dipengaruhi oleh testosteron, yang berubah menjadi DHT karena pengaruh enzim 5-alfa reduktase dalam sitoplasma sel genitalia eksterna dan sinusurogenital. DHT di berikan dengan reseptor androgen dalam sitoplasma kemudian ditranspor ke nukleus. Menyebabkan translasi dan transkripsi material genetik. Akhirnya menyebabkan perkembangan genetalia eksterna laki-laki normal. Kemudian pada fase gestasi selanjutnya testosteron bertanggung jawab terhadap pertumbuhan falus yang responsif terhadap testosteron dan DHT.

\section{PEMERIKSAAN FISIK}

Bayi baru lahir, patut dicurigai menderita kelainan ambiguous genetalia bila ditemukan memiliki bentuk alat kelamin luar yang berbeda dari normal. Manifestasi atau bentuk alat kelamin luar bayi yang berkemungkinan ambiguous genitalia antara lain:2,5

1. Tampak sebagai laki-laki

- Testes tidak teraba pada bayi aterm

- Hipospadi disertai kantung skrotum terbelah

- Kriptorkidisme dengan hipospadi

2. Meragukan/indeterminate

- Ambiguous genitalia

3. Tampak sebagai perempuan

- Hipertropi klitoris dalam berbagai derajat

- Vulva dangkal hanya dengan satu lubang

- Hernia inguinalis yang berisi gonad

Diagnosis kelainan ambiguous genetalia ini memerlukan anamnesis terhadap orang tua bayi, antara lain tentang riwayat keluarga/keturunan; riwayat penyakit, gizi, dan konsumsi obat selama kehamilan; riwayat penyakit dahulu, pola hidup sehari-hari,dan lain sebagainya. Pada bayi dilakukan observasi yang lebih teliti pada organ genital dan anal serta daerah perineum, diikuti palpasi daerah perineal dan lipatan paha untuk meraba adanya gonad/testis. Pada bayi atau anak yang lebih besar diperlukan anamnesis dan pengamatan tentang tumbuh kembang anak.

\section{PEMERIKSAAN PENUNJANG}

\section{a. Pemeriksaan darah}

- Serum elektrolit

- kadar gula darah

- kadar reseptor androgen

- kadar hormon (17-OH progesteron, LH, FSH, rasio 
testosteron/DHT)

\section{b. Analisa kromosom}

Dua cara untuk melakukan tes kromosom ini yaitu:

- Kariotyping

Pemeriksaan genetika untuk memastikan bahwa karyotipe bayi/anak adalah $\mathrm{XY}$ atau $\mathrm{XX}$ atau mungkin yang lain (XO, XXY atau lainnya).

- Fluorescent in situ hybridisation (FISH) analysis

Biasanya digunakan untuk mendeteksi delesi atau adisi kromosom submikroskopik (sangat kecil).

Selanjutnya dilakukan pemeriksaan radiologi (USG/scaning), biokimia, dan genetika. Pemeriksaan radiologis diperlukan untuk melihat anatomis alat kelamin dalam. ${ }^{6}$

\section{c. Tes Biokimiawi}

Untuk melihat jumlah atau aktivitas dari keyprotein. Gen mengandungi kode DNA untuk membuat protein. Sekiranya ada abnormalitas pada jumlah atau aktivitas dari protein menampakkan signal adanya gen yang tidak berfungsi secara abnormal. Misalnya, skrining biokimia dapat mendeteksi bayi yang ada kondisi metabolik seperti bayi dengan genital ambiguous karena kekurangan enzim 5-alfa reduktase. ${ }^{6}$

\section{WORKING DIAGNOSIS}

\section{Disorder of Sexual Development}

The Lawson Wilkins Pediatric Endocrine Society (LWPES) dan the European Society for Paediatric Endocrinology (ESPE) telah melakukan perubahan atas tata nama dan definisi gangguanperkembangan seks kromosom, gonad, atau fenotipikl. Berikut adalah daftar istilah dan tata nama sebelumnya direvisi. ${ }^{9}$

\section{Terminologi dan Nomenclature Gangguan Perkembangan Seksual}

\section{Sebelumnya}

Female pseudohermaphrodite

Male pseudohermaphrodite

True hermaphrodite

$\mathrm{XX}$ male

$\mathrm{XY}$ sex reversal

\author{
Setelah revisi \\ 46,XX DSD \\ 46,XY DSD \\ Ovotesticular DSD \\ 46,XX testicular DSD \\ 46,XY complete - \\ gonadal dysgenesis
}

\footnotetext{
Klasifikasi DSD berdasarkan kriteria terbaru

- Sex chromosome DSD

- $\quad 45, X$ (Turner syndrome and variants)

- 47,XXY (Klinefelter syndrome and variants)

- 45,X/46,XY (mixed gonadal dysgenesis, ovotesticular DSD)

- 46,XX/46,XY (chimeric, ovotesticular DSD)

- 46,XY DSD

- Disorders of testicular development (complete and
}

partial gonadal dysgenesis)

- Disorders of androgen synthesis (complete and partial androgen insensitivity, disorders of antimüllerian hormone $[A M H] /$ receptor, androgen biosynthesis defect)

- Other (severe hypospadias, cloacal exstrophy)

- 46,XXDSD

- Disorders of ovarian development (ovotesticular DSD, testicular DSD, gonadal dysgenesis)

- Androgen excess (fetal [eg, congenital adrenal hyperplasia $(\mathrm{CAH})$ ], fetoplacental, maternal)

- Other (vaginal atresia, cloacal exstrophy)

Penatalaksanaan Disorder of sex development (DSD)

Penatalaksanaan optimal untuk disorder of sex development(DSD) membutuhkan peran dari tim multidisiplin ilmu, meliputi lingkup psikososial, medis, dan pembedahan serta disiplin ilmu subspesialis lainnya seperti neonatologi, endokrinologi, urologi, ginekologi, ahli genetik, konselor, psikiater atau ahli psikologi, perawat dan pekerja sosial. , $^{910}$

\section{Lingkup Penanganan Psikososial}

Manajemen psikososial pada DSD diantaranya adalah dengan melakukan gender assignment $\mathcal{E}$ reassignment. Gender assignment (menentukan identitas kelamin) sebaiknya dilakukan pada masa neonatus. Semakin lama menunda penentuan jenis kelamin, dapat menimbulkan risiko terjadinya penolakan terhadap eksistensi anak penderita DSD oleh kedua orangtua yang diperkirakan dapat mengganggu aspek tumbuh kembang anak terutama pada perkembangan organ reproduksi selanjutnya. Semakin lama penentuan jenis kelamin akan berpengaruh pula pada prognosis dan pemilihan terapi yang akan menentukan kapan dimulainya pemberian terapi hormonal, jenis terapi hormonal yang dipilih serta lama pemberiannya, pemilihan waktu yang tepat untuk pembedahan, hingga potensi seksualitas dan fertilitas pada DSD di usia dewasa yang mempengaruhi kualitas hidupnya. Jika penentuan jenis kelamin masih sulit ditentukan, sebaiknya para ahli yang menangani rutin memberikan penjelasan dan konseling terhadap pihak orang tua sehingga dapat memulai adaptasi terhadap kondisi yang dihadapi. ${ }^{9,10}$

Dalam tatalaksana DSD dapat pula dilakukan gender reassignment (menentukan kembali identitas kelamin). Usia 18 bulan dianggap sebagai batas atas dalam melakukan gender reassignment. Jika gender reassignment baru dilakukan pada usia balita atau usia anak-anak, evaluasi psikososial sangat penting, karena sudah terjadi perkembangan perilaku berdasarkan jenis kelamin yang baru. Manajemen informasi kepada anak penderita DSD oleh konselor merupakan hal yang penting dipahami. Dengan melakukan manajemen informasi yang baik, diharapkan penyandang DSD dapat 


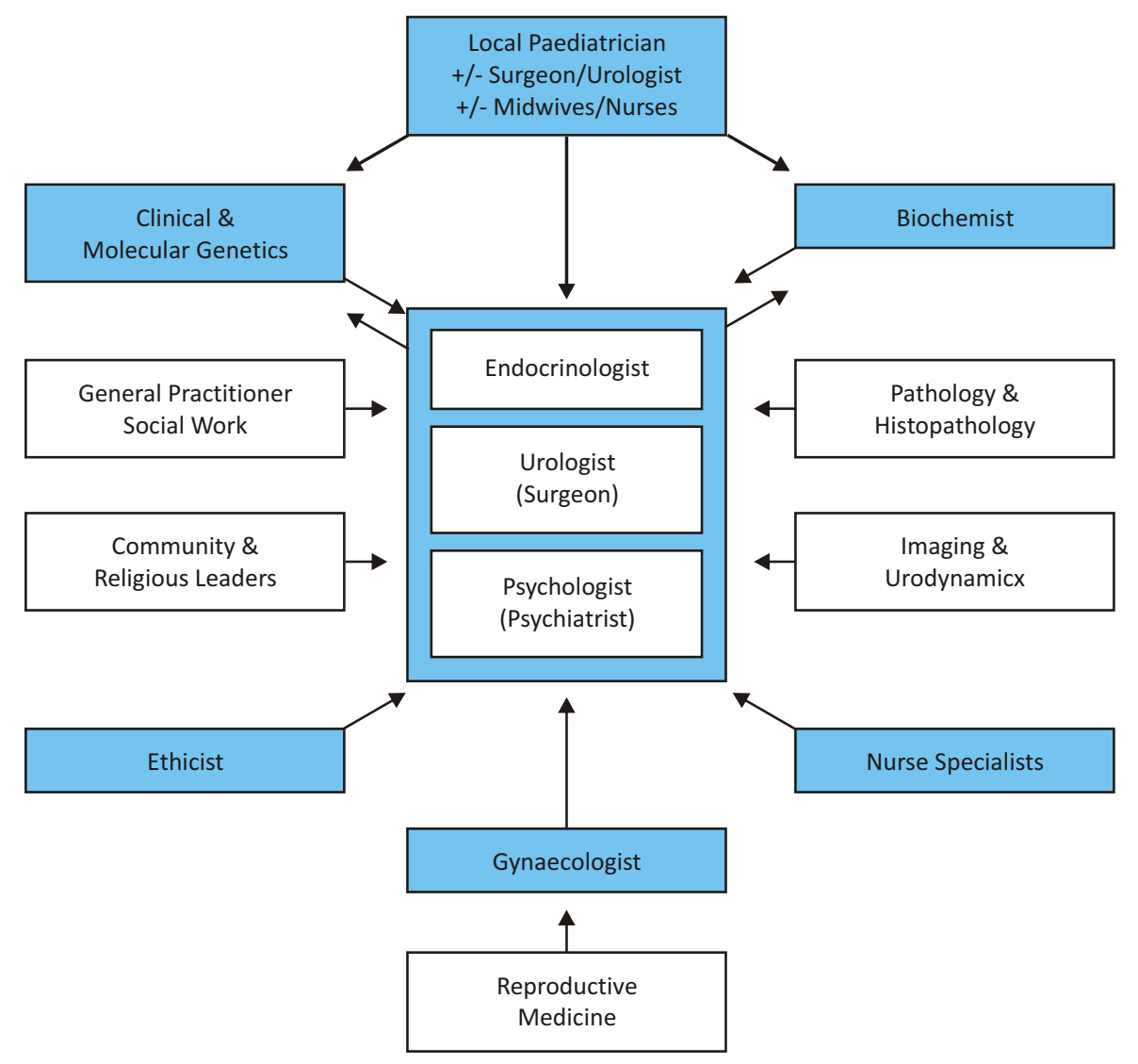

menerima kondisinya saat ini, mampu menjalankan terapi yang berkesinambungan, serta mendapat edukasi mengenai perkembangan pubertas, seksualitas, dan kemungkinan potensi fertilitas dimasa mendatang. Manajemen informasi juga diberikan kepada orangtua anak dengan DSD terkait dengan kondisi, prognosis, dan pengetahuan orangtua tentang DSD. ${ }^{9,11}$

Metode lain dalam lingkup psikososial yang dapat dilakukan adalah dengan membentuk support groups. Adanya support groups membantu menimbulkan rasa kepercayaan diri, saling membantu antar sesama dan meningkatkan kualitas hidup, serta mampu menimbulkan rasa dukungan dari pihak keluarga., 511

\section{Lingkup Penanganan Medikamentosa}

Penatalaksanaan medikamentosa meliputi pemberian terapi hormonal. Pemberian terapi hormonal termasuk dalam upaya pemeriksaan untuk menegakkan diagnosis DSD sesuai dengan klasifikasinya. Pemberian terapi hormon pada DSD berdasarkan atas kebutuhan hormon seks untuk menginisiasi maturasi pubertas. Terapi hormonal ini dapat dilakukan pada saat usia penyandang DSD memasuki usia pubertas. Jika terlalu lama menunda terapi hormon dapat menimbulkan keterlambatan perkembangan genitalia, fungsi reproduksi dan fungsi seksual serta mempengaruhi kualitas hidupnya di masa mendatang., 9,11

Bila pasien menjadi laki-laki, tujuan pengobatan untuk mendorong perkembangan maskulinasi dan menekan perkembangan feminisasi. Bila perkembangan mengarah kepada perempuan maka tujuan pengobatan adalah mendorong karakteristik seksual ke arah feminim dan menekan perkembangan maskulin. Pada congenital adrenal hyperplasia (CAH) diberikan glukokortikokoid dan hormon untuk retensi garam. Pengobatan dengan hormon seks biasanya dimulai pada saat pubertas dan glukokortikoid dapat dilakukan lebih awal bila diperlukan, biasanya dimulai saat diagnosis ditegakkan. ${ }^{11,12}$

\section{Lingkup Penanganan Pembedahan}

Terapi pembedahan berupa genitoplasty dapat dilakukan jika diagnosis sudah ditegakkan dan hasil luaran pasca operasi bermanfaat dalam penentuan jenis kelamin di usia dewasa. Genitoplasty merupakan jenis terapi yang bersifat irreversible seperti dilakukannya kastrasi dan reduksi phallus pada DSD yang akan menjadi wanita dan reseksi utero-vagina pada DSD yang akan menjadi pria. Pemilihan terapi pembedahan tidak boleh dilakukan sebelum dilakukan pemeriksaan endokrin dan 


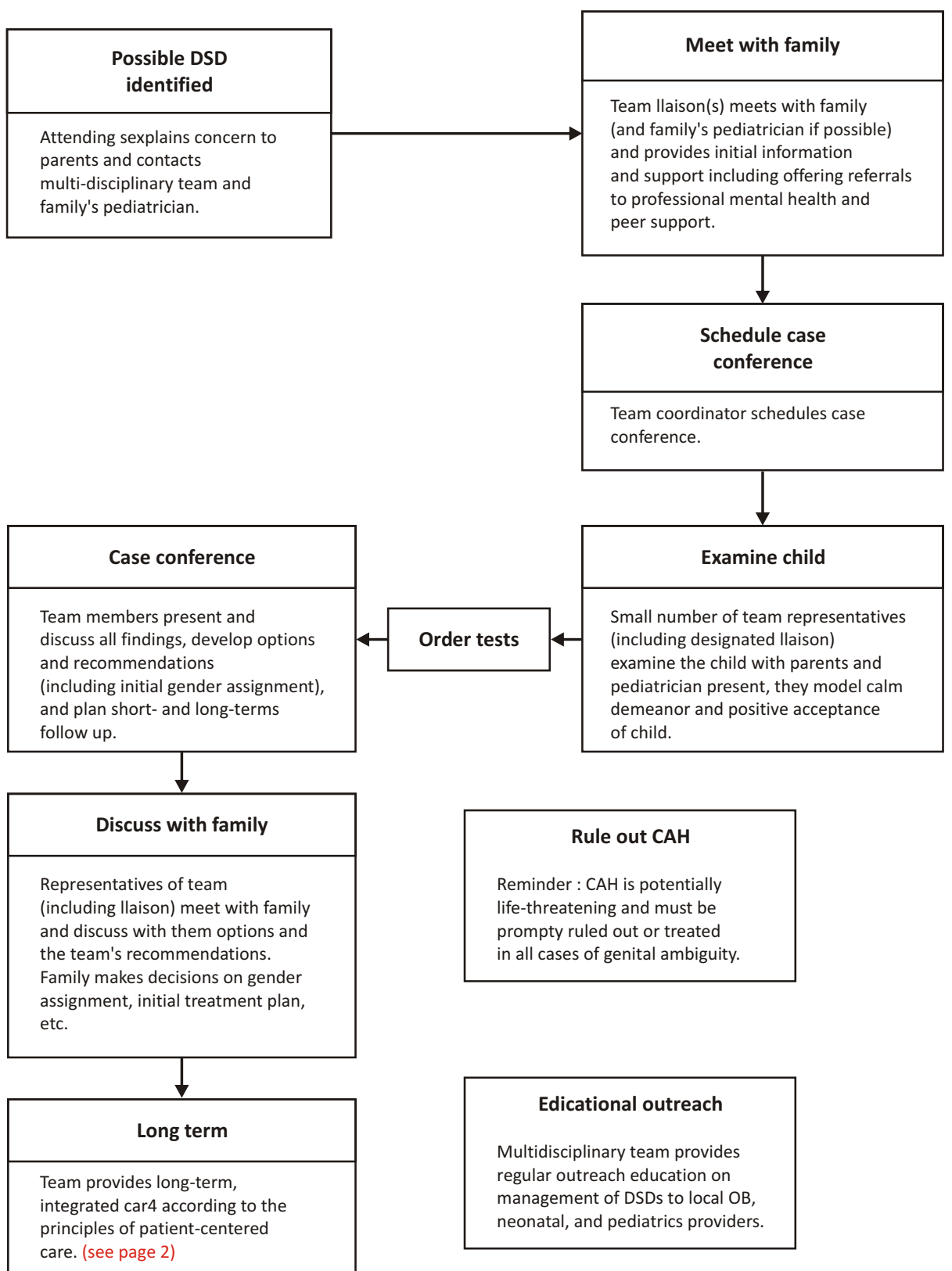

pendekatan terapi psikososial. Seluruh jenis tindakan pembedahan yang akan dilakukan harus dipertimbangkan secara hati-hati, dengan mengutamakan kepentingan pasien. . $^{10,11}$

Penentuan usia yang tepat untuk menentukan waktu yang tepat untuk operasi masih diperdebatkan. Berdasarkan aspek psikososial, tindakan operasi yang dilakukan pada masa infant lebih disukai, karena lebih mudah dilakukan dan riwayat trauma operasi dapat dihilangkan jika dibandingkan dengan melakukan pembedahan pada anak saat memasuki usia dewasa. Namun, pendapat lain menyatakan bahwa tindakan operasi DSD sebaiknya menunggu sampai usia yang cukup untuk menerima informasi dan selanjutnya dilakukan informed consent langsung kepada penyandang DSD, karena berhubungan dengan fungsi seksualitas. ${ }^{10-12}$

Tujuan utama tindakan pembedahan adalah mengembalikan fungsi organ genitalia dibandingkan fungsi estetiknya. Tujuan lainnya adalah menentukan jenis kelamin yang tepat, membantu pembentukan image tubuh sesuai dengan jenis kelaminnya, menghindari stigma sosial, dan fungsi seksualitas dalam berhubungan seksual.11,12

Tujuan pembedahan rekonstruksi pada perempuan adalah membentuk genitalia eksterna feminin, supaya bentuk dan fungsi mendekati normal. 
Pembedahan ini dilakukan secara bertahap, tahap pertama mengkoreksi ukuran clitoris yang terlalu besar, dan tahap kedua dilakukan untuk mengkoreksi bentuk vagina. Pada laki-laki koreksi bertujuan untuk mengkoreksi bentuk penis dan urethra, biasanya dapat dengan satu tahapan operasi, kecuali pada kasus yang sulit. 11,12

Setelah menjalankan operasi, penatalaksanaan lainnya yaitu aspek psikososial dan medikamentosa harus dijalani secara teratur. Rangkaian penatalaksanaan ketiganya saling mendukung satu sama lain. Terapi pembedahan gonad saat ini juga dinilai penting, terutama pada kasus 46XY DSD, dimana umumnya testis masih tetap berada di dalam rongga abdomen. Kemungkinan adanya diferensiasi gonad ke arah keganasan membuat terapi pengangkatan gonad dibutuhkan. Pemeriksaan biopsy gonad kadang juga diperlukan untuk membuktikan adanya kelainan disgenesis gonad atau adanya kondisi ovotestis. ${ }^{11}$

\section{SIMPULAN}

Disorders of sex development merupakan suatu kelainan yang terjadi akibat perkembangan anatomis organ kelamin yang tidak sempurna pada saat embrio. Penanganan penderita ambiguous genetalia harus dilakukan secara holistic karena dampaknya tidak hanya sebatas masalah medis namun juga psikologis, sosial bahkan hukum. Oleh karena itu penanganannya harus melibatkan beberapa disiplin ilmu dengan tim multidisiplin.

\section{DAFTAR PUSTAKA}

1. Achermann JC, Hughes IA. Disorders of sex development. Williams Textbook of Endocrinology. Philadelphia: Saunders Elsevier; 2008; p.783-838

2. John C. Achermann, J. Larry Jameson. Disorder of Sex Development. Harrison's Principle of Internal Medicine $18^{\text {th }}$ ed. $2012 ; 876-880$

3. Sultana. Mh Faradz. Kelamin Ganda Penyakit atau Penyimpangan Gender. Diunduh dari : Http://Www.Fk.Undip.Ac.Id/ Artikel-Lepas/KelaminGanda-Penyakit-Atau-Penyimpangan-Gender.Html,/ Diakses pada 22 November 2016

4. MacLaughlin DT, Donahoe PK. Sex Determination and Differentiation. 2004. NEngl JMed;350:367-378.

5. Susanto R. Profil Hormonal Pada Anak Dengan Ambigus Genitalia.2004. In: Proceedings of The National Seminar And Workshop on Ambiguous Genitalia. Semarang

6. Becker LK. Principles And Practice of Endocrinology And Metabolism, Philadelphia. Lippincott and Wilkins $3^{\text {rd }}$ ed.2000

7. Meyer-Bahlburg HFL. Treatment guidelines for children with disorders of sex development. Neuropsychiatric de I'enfance et de I'adolescense.2008;56.p.345-49.

8. Mendoca BB, Domenice S, Arnhold I, Costa E. 46,XY Disorders of sex development (DSD). Clinical Endocrinology. 2009; 70: 173-187.

9. Anthony E, Aspinall CA, Baratz AB, Boney C, Brown DR, Byne $W$ et al. Clinical guidelines for the management of disorders of sex development in chilhood. Consortium on The Management of Disorders of Sex Development. 2006.

10. Brain CE, Creighton SM, Mushtag I, Carmichael PA, Barnicoat A, Honour JW, et al. Holistic management of DSD. Best Practice \& Research Clinical Endocrinology \& Metabolism. 2010;24:335-54.

11. Diamond DA, Burns JP, Mitchell C, et al. Sex assignment for newborns with ambiguous genitalia and exposure to fetal testosterone: attitudes and practices of pediatric urologist. J Pediatr.2006;148:445-9.

12. Widhiatmoko B, Suyanto E. Legalitas perubahan jenis kelamin pada penderita ambiguous genitalia di Indonesia. Jurnal Kedokteran Forensik Indonesia. 2013;15(1);12-22. 